\title{
Ingestive behavior of Girolando heifers in integrated crop, livestock (ICL), and forestry (ICLF) systems
}

\author{
[Comportamento ingestivo de novilhas Girolando mantidas em sistemas de integração \\ lavoura-pecuária (ILP) e lavoura-pecuária-floresta (ILPF] \\ E.C. Souza ${ }^{1}$, A.K.D. Salman ${ }^{2 *}$, P.G. Cruz ${ }^{2}$, G.A. Carvalho ${ }^{1}$, F.R.F. Silva ${ }^{3}$ \\ ${ }^{1}$ Aluno de pós-graduação - Universidade Federal de Rondônia - Porto Velho, RO \\ ${ }^{2}$ Empresa Brasileira de Pesquisa Agropecuária - Embrapa Rondônia - Porto Velho, RO \\ ${ }^{3}$ Aluno de pós-graduação - Universidade Federal de Rondônia - Rolim de Moura, RO
}

\begin{abstract}
Aiming to compare integrated crop, livestock (ICL) and forest (ICLF) systems in relation to ingestive behavior of dairy heifers, a $2 \times 2$ crossover trial was conducted with two periods and two systems. Eight Girolando (3/4holstein $\times 1 / 4 \mathrm{Gyr}$ ) heifers were evaluated in pasture of Xaraés palisade grass (Urochloa brizantha 'Xaraes' syn Brachiaria brizantha) managed with intermittent stocking. The ICLF systemhad eucalyptus trees planted in tiers with $65 \%$ crown cover. Ingestive behavior parameters were obtained using acoustic data collected with $\mathrm{mP} 3$ recorders for 48 hours. Statistical analysis was performed using the mixed procedure of SAS, and means were compared using the Tukey-Kramer test at 5\% significance. The dry mater intake (DMI), number of daily grazing sessions, and the duration of the grazing sessions did not differ $(P<0.05)$ between systems. A higher $(\mathrm{P}<0.05)$ bite rate and total daily bites and lower $(\mathrm{P}<0.05)$ bite mass was observed in the ICLF system in relation to ICL. Heifers in shaded pasture change their ingestive behavior in comparison with those in full-sun pasture.
\end{abstract}

Keywords: agrosilvo pastoral systems, dairy cattle, bite rate, natural shading

\section{RESUMO}

Com o objetivo de comparar sistemas de integração lavoura-pecuária (ILP) e lavoura-pecuária-floresta (ILPF) em relação ao comportamento ingestivo de novilhas leiteiras, conduziu-se um ensaio em delineamento crossover $2 \times 2$, com dois períodos e dois sistemas. Oito novilhas Girolando foram mantidas em pastagens de capim-xaraés (Urochloa brizantha 'Xaraes' syn Brachiaria brizantha) manejadas com lotação intermitente. No sistema ILPF, havia renques de eucalipto com $65 \%$ de cobertura de copa. $O$ comportamento ingestivo foi avaliado pela análise de áudios coletados com gravadores de Mp3, durante 48 horas. As análises estatísticas foram realizadas utilizando-se Proc mixed SAS. As médias foram comparadas pelo teste Tukey-Kramer, ao nível de 5\% de significância. A ingestão de matéria seca (IMS), o número de sessões de pastejo por dia e a duração das sessões de pastejo não diferiram $(P<0,05)$ entre os sistemas. As maiores $(P<0,05)$ médias de taxa de bocado e de número de bocados por dia e a menor $(P<0,05)$ média de massa de bocado foram observadas no ILPF quando comparado ao ILP. Novilhas em pastagem sombreada alteram seu comportamento ingestivo quando comparadas àquelas que são mantidas em pastagem a pleno sol.

Palavras-chave: agrossilvipastoril, bovinocultura leiteira, taxa de bocado, sombreamento natural

\section{INTRODUCTION}

Grazing animals need to maintain constant forage intake throughout the day in order to meet their nutritional requirements. However, they have faced the problem of obtaining these nutrients from a complex and heterogeneous environment, where the sward structure and accessibility as well as the quantity and quality of the nutrients are variable (Ferreira et al., 2013). Forage

Recebido em 2 de setembro de 2020

Aceito em 9 de fevereiro de 2021

*Autor para correspondência (corresponding author)

E-mail: ana.salman@embrapa.br 
consumption should be controlled by animal ingestive behavior (Sampaio et al., 2016). For this reason, understanding the animal-plant relationship during grazing behavior is very important. This means to determine how animals adjust their ingestive behavior according to changes in sward structure and pasture environment, aiming to adjust feeding handling according to the maximum animal production potential (Costa et al., 2011; Mezzalira et al., 2011).

Bovine ingestive behavior can be evaluated by the variables grazing time, bite rate, and bite mass, which are influenced by the sward structure. In order to maintain constant dry mater intake and reach their daily nutritional requirements, animals undergo behavioral changes, such as increasing or decreasing grazing time, and changing the number of jaw movements for harvesting and processing fodder according to its height, density, leaf:stem ratio, and the spatial arrangement of sward leaves (Camargo et al., 2012; Yayota et al., 2015).

The integrated crop-livestock-forest (ICLF) production system integrates crop, livestock, and forest components in rotation, combination, or succession in the same area. It has been applied to improve the soil use, to diversify agricultural production, to restore soil quality and pasture areas, and to contribute to cattle ranching, especially in terms of animal welfare (Balbino et al., 2011; Freitas et al., 2013; Lima et al., 2018). However, due to shading from trees in the pasture area, changes in the forage morphophysiology are observed, such as an increase in leaf area, accompanied by a decrease in leaf blade thickness, which result in higher values of specific leaf area in shaded environments (Lopes et al., 2017).

Because of changes in plant morphophysiology, the patterns of bovine ingestive behavior may be affected, such as the bite size, the number of bites per unit time, grazing time, and animal consumption and performance (Gobbi et al., 2009; Yayota et al., 2015; Santos et al., 2018). The hypothesis of this study is that Girolando heifers modify their ingestive behavior according to differences in pasture structure within integrated crop-livestock (ICL) and integrated crop-livestock-forest (ICLF) systems.

\section{MATERIAL AND METHODS}

The Ethics Committee for Animal Utilization of Brazilian Agricultural Research Corporation (Embrapa Rondônia) approved all the management practices applied to experimental animals (process number 06-2015). Trials were carried out in the experimental field of Embrapa, Porto Velho, Rondônia, Brazil (848'03.89" S and $63^{\circ} 50^{\prime} 53.08^{\prime \prime}$ W) from September $10^{\text {th }}$ to November $11^{\text {th }}, 2015$. The predominant climate in this region is Am according to the Köppen classification actualized by Alvares et al. (2014). This is characterized by a dry season (from May to September) and a rainy season (from October to April). The means of annual air temperature and annual rainfall are $26^{\circ} \mathrm{C}$ and $2095 \mathrm{~mm}$, respectively.

Eight $25 \pm 6.8$ month-old Girolando (3/4holstein $\times$ $1 / 4 \mathrm{Gyr}$ ) heifers with an initial live weight (LW) of $268 \pm 83 \mathrm{~kg}$ were used. They were distributed in a $2 \times 2$ crossover design between two ICLF and ICL systems. There were two 30-day experimental periods (period 1 and period 2), 10 days for adaptation, and 20 days for data collection, with a total of 60-days of experimental period. An area of 10ha was divided into two 5-ha areas for each of the ICL and ICLF systems. In each area, the pasture of Xaraés palisade grass (Urochloa brizantha 'Xaraes' syn Brachiaria brizantha) was divided into four paddocks of $1.25 \mathrm{ha}$ and managed by intermittent grazing (10 days of occupation and 30 days of resting periods) at a stocking rate of 2.5 animal unit (AU) per ha. In the center of each pasture system, there was a place for offering water and mineral salt mix ad libitum.

The ICLF system had seven tiers of four rows each of eucalyptus trees planted in March 2013 at a $3 \times 3 \mathrm{~m}$ plant spacing. At the beginning of the trial, the trees had an average diameter at breast height of $11.9 \pm 2.7 \mathrm{~cm}$, total height $13.8 \pm 2.5 \mathrm{~cm}$, and crown cover $65 \%$. To estimate the forage allowance, the forage was sampled in $1 \mathrm{~m}^{2}$ plots randomly placed in different areas of the paddock before the occupation period. The sward height was measured with a $100-\mathrm{cm}$ ( $1 \mathrm{~mm}$ scale) graduated ruler just before cutting (10cmheight) and weighing with a portable digital dynamometer (DD2000 Instrutherm ${ }^{\circledR}$, São Paulo, Brazil). Grass samples were oven-dried at $65^{\circ} \mathrm{C}$ to 
constant weight to determine the dry matter (DM) content.

The forage bulk density (FBD) was estimated according to Lopes et al. (2017):

Where:

$$
\text { FBD }\left(\text { DMkg.ha }^{-1} \cdot \mathrm{cm}^{-1}\right)=\text { FA } \times \text { height }^{-1}
$$

FA = forage allowance within sward (kg DM.ha $\left.{ }^{-1}\right)$

Height $=$ height of forage sward $(\mathrm{cm})$

Forage dry matter intake (DMI) was estimated using the equation:

Forage DMI $\left(\mathrm{kg}\right.$ DM.day $\left.{ }^{-1}\right)=$ TFP $\times\left(1-\right.$ IVDMD $^{-1}$

Where:

TFP $=$ total fecal production $\left(\mathrm{kg}\right.$ fecal DM.day $\left.{ }^{-1}\right)$

IVDMD = in vitro DM digestibility (\%)

Total fecal production was estimated using the external digestive marker LIPE® (Produtos de Pesquisas Simões e Saliba, Belo Horizonte, MG, Brazil). One dose $(500 \mathrm{mg})$ per animal was provided each morning for seven days, following the manufacturer's recommendations. From the third day, feces were collected directly from the animal's rectum. Then, feces samples were ovendried at $65^{\circ} \mathrm{C}$ until a constant weight was achieved, and dried 1-mm samples were sent to the laboratory for analysis (Machado et al., 2011).

In pastures of both systems, Xaraés palisade grass samples were taken by hand-plucking (Prohmann et al., 2012) during four consecutive days (from the $3^{\text {rd }}$ to $6^{\text {th }}$ day of the paddock occupation period). The samples were oven-dried at $65^{\circ} \mathrm{C}$ until a constant weight was achieved. Dried 1-mm samples were analyzed for DM, crude protein (CP), neutral detergent fiber (NDF), acid detergent fiber (ADF), and lignin (LIG) following the methodologies of the National Institute of Science and Technology of Animal Science (INCT-CA) reported by Detmann et al. (2012). The determination of in vitro DM digestibility (IVDMD) of the diet was adapted from ANKOM (2017). The chemical composition and digestibility of Xaraés palisade grass, as well as the forage allowance in pastures of both systems are shown in Table 1. The forage bulk density (FBD) and sward height of Xaraés palisade grass are shown in Table 2.

Table 1. Forage allowance, chemical composition, and digestibility of Xaraés palisade grass in integrated crop livestock (ICL) and integrated crop livestock forestry (ICLF) systems

\begin{tabular}{|c|c|c|c|c|c|c|c|}
\hline \multirow[t]{2}{*}{ System } & \multirow{2}{*}{$\begin{array}{c}\text { Forage } \\
\text { allowance } \\
\left(\mathrm{kg} \mathrm{DM}^{2} 100 \mathrm{~kg}\right. \\
\left.\mathrm{BW}^{-1}\right)\end{array}$} & \multirow[t]{2}{*}{$\mathrm{DM}(\%)$} & $\mathrm{CP}$ & NDF & $\mathrm{ADF}$ & LIG & \multirow[t]{2}{*}{$\begin{array}{c}\text { IVDMD } \\
(\%)\end{array}$} \\
\hline & & & \multicolumn{4}{|c|}{$\% \mathrm{DM}$} & \\
\hline ICL & 41.9 & 30.6 & 9.5 & 59.9 & 27.5 & 2.2 & 75.64 \\
\hline ICLF & 32.3 & 25.9 & 12.5 & 60.2 & 28.8 & 2.5 & 72.83 \\
\hline
\end{tabular}

$\overline{\mathrm{DM}}$, dry matter; CP, crude protein; NDF, neutral detergent fiber; ADF, acid detergent fiber; LIG, lignin; BW, body weight, IVDMD, in vitro dry matter digestibility.

Table 2. Forage bulk density (FBD) and sward height of Xaraés palisade grass in integrated crop livestock (ICL) and integrated crop livestock forestry (ICLF) systems

\begin{tabular}{|c|c|c|}
\hline System & FBD $\left(\right.$ DMkg $\left.\mathrm{ha}^{-1} \cdot \mathrm{cm}^{-1}\right)$ & Height $(\mathrm{cm})$ \\
\hline ICL & 68.3 & 76.6 \\
\hline ICLF & 55.9 & 97.0 \\
\hline
\end{tabular}

DM - Dry matter.

Grazing behavior was observed from $14^{\text {th }}$ to $16^{\text {th }}$ day of the experimental period using acoustic data (Veit et al., 2018). Audios were captured bymP3 recorders (model PX240, Sony® Corporation, Japan) tied to the heifer's halters for continuously registering the grazing sounds during $48 \mathrm{~h}$. Audios were reproduced using Audacity® software.
Following Thurow et al. (2009), the number of grazing sessions throughout the day and their duration were identified, considering a grazing period to be more than five minutes and not interrupted for more than five minutes by another activity (Figure 1A). 
The bite rate (BR) was determined during the grazing activity of each animal, considering bites to be characterized by sounds of prehension and breaking the leaves by the animal, which had a greater intensity than chewing sounds (Figure
1B). From these data, a stopwatch was used to measure the time (minutes) spent by the animal to produce 20 bites, which was then converted to bites per minute (Jamieson and Hodgson, 1979).

A)

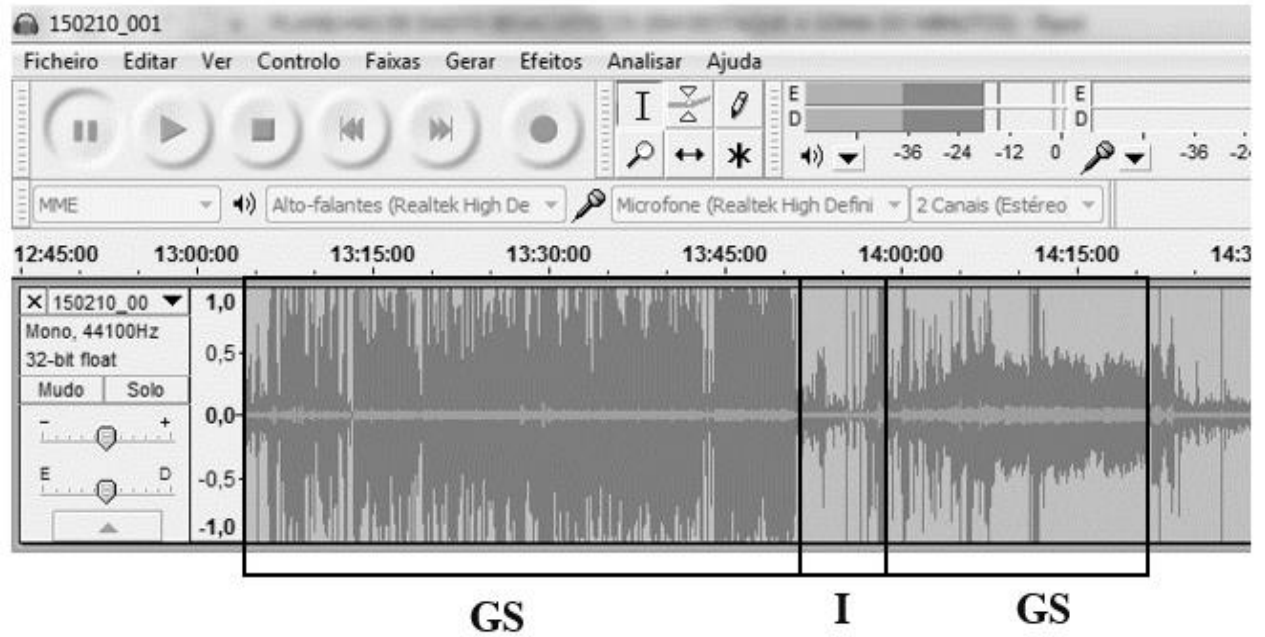

B)

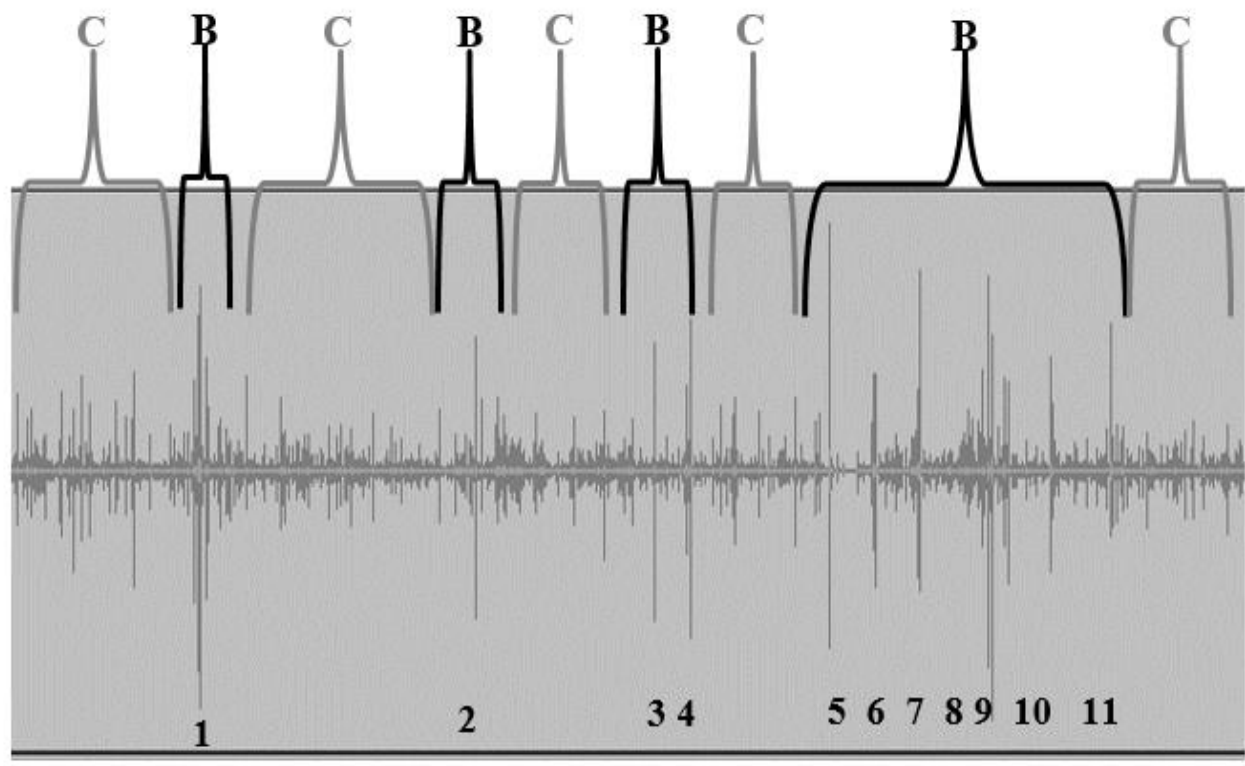

Figure 1. Screenshot of Audacity® during the reproduction of soundtracks: A is an oscillogram of sound of two grazing sessions (GS) with an interval (I) between them; and B is an oscillogram of a sequence of sounds of bites (B) and chewing (C); the numbers 1 to 11 is the counting of bites (peak of sounds). Source: Audacity® (2018). 
The number of daily total bites (TB) was obtained according to Baggio et al. (2009):

$$
\mathrm{TB}\left(\text { n.day }{ }^{-1}\right)=\mathrm{BR} \times \mathrm{GT}^{-1}
$$

Where:

$\mathrm{BR}=$ bite rate (bites. $\left.\mathrm{min}^{-1}\right)$;

$\mathrm{GT}=$ grazing time $(\mathrm{min})$

The bite mass (BM) was estimated according to the method of Jamieson and Hodgson (1979):

Where:

$$
\mathrm{BM}\left(\mathrm{g} \mathrm{DM} \cdot \mathrm{bite}^{-1}\right)=\mathrm{DMI} \times \mathrm{TB}^{-1}
$$

$\mathrm{BM}=$ bite mass;

DMI = dry matter intake $\left(\mathrm{kg} \mathrm{DM} \cdot\right.$ day $\left.^{-1}\right)$;

$\mathrm{TB}=$ daily total bites $\left(\right.$ n.day $\left.{ }^{-1}\right)$.

Statistical analysis of the data was performed using SAS (Statistical Analysis System Institute Inc., Cary, NC) MIXED procedure model:

Where:

$$
Y_{i j k l}=\mu+S_{i j}+P_{k}+T_{l}+e_{i j k l}
$$

$\mathrm{Y}_{i j k l}$ : is the observation $i j k l$;

$\mu$ : is the overall mean.

$\mathrm{S}$ : is the effect of animal $i$ (1 to 8) within the sequence $j$ (1 or 2$)$

$\mathrm{P}:$ is the fixed effect of period $k$ ( 1 or 2$)$

$\mathrm{T}$ : is the fixed effect of production system $l$ (ICL or ICLF)

$e_{\mathrm{ijkl}}$ is the random error.

Means were compared using the Tukey-Kramer test at the $5 \%$ significance level.

\section{RESULTS AND DISCUSSION}

The bite rate (BR) and daily total bite (TB) of Girolando heifers were different $(\mathrm{P}<0.05)$ between the systems, with higher values being found within the ICLF than in the ICL (Table 3). Generally, the BR is related to the height of the forage sward. Under conditions of greater sward height, animals tend to decrease the BR and grazing time due to the higher bite mass (BM), which causes changes in the $\mathrm{TB}$, since this is the product of the BR and grazing time (Rocha et al., 2016; Sampaio et al., 2016). Despite the greater height of Xaraés palisade grass in the ICLF system than in the ICL (Table 3), there was no decrease in the BR of animals grazing in the ICLF. This may be related to the volumetric density of the forage, which was greater in the ICL system (Table 2), which resulted in a greater BM (Table 3). Consequently, a lower BR was found in the ICL system because animals take longer to swallow a bite with higher volume because the chewing time per bite is longer (Hirata et al., 2010; Teixeira et al., 2010; Galli et al., 2018).

The smaller BM of animals in the ICLF system (Table 3) may be related to the integration between the forest component and pasture. Shading forage changes its morphophysiological characteristics, such as decreased tillering and number of leaves per tiller and tends to have higher leaves as an adaptation for reaching the light (Geremia et al., 2018), which explains the lower forage density and greater sward height in this system when compared to the ICL system (Table 2). The BR verified in both systems (ICL and ICLF) (Table 3) were similar to the value of 26.85 bite. $\mathrm{min}^{-1}$ reported by Souza et al. (2011) for beef heifers in different grazing situations. However, they are below the range of 40-70 bites. $\mathrm{min}^{-1}$ reported for growing cattle (Delagarde et al., 2001). The daily TB (Table 3) was similar to the values of 9,865 to 11,159 bites found by Suárez et al. (2014) in beef steers grazing hybrid grass $B$. ruziziensis $\times B$. decumbens $\times B$. brizantha mulato II (CIAT 36087) in a tropical region of Colombia. These values are considered low, since cattle can perform more than 35,000 prehension actions during the day (Carvalho et al., 2001; Werner et al., 2019).

Table 3. Mean bite rate (BR), daily total bite (TB), bite mass (BM), number of grazing sessions, and

\begin{tabular}{|c|c|c|c|}
\hline \multirow{2}{*}{ Variables } & \multicolumn{2}{|c|}{ Systems } & \multirow{2}{*}{$P$} \\
\hline & ICL & ICLF & \\
\hline BR (bite. $\min ^{-1}$ ) & $23.57 \mathrm{~b}$ & $28.52 \mathrm{a}$ & 0.0491 \\
\hline DTB $\left(\right.$ n.day $\left.{ }^{-1}\right)$ & $9.124 \mathrm{~b}$ & $12.304 \mathrm{a}$ & 0.0220 \\
\hline BM (g DM.bite $\left.{ }^{-1}\right)$ & $1.11 \mathrm{a}$ & $0.7 \mathrm{~b}$ & 0.0083 \\
\hline Grazing sessions $\left(\right.$ n.day $\left.{ }^{-1}\right)$ & 9 & 8 & 0.3196 \\
\hline Duration of grazing session (min) & 44.72 & 49.04 & 0.6501 \\
\hline
\end{tabular}
duration of grazing sessions for Girolando heifers in integrated crop-livestock (ICL) and integrated croplivestock-forest (ICLF) systems

Means followed by different letters in rows are different by the Tukey-Kramer test at $5 \%$ significance. 
The low values of BR and TB can be related to the BM (Table 3), which depends on the sward height. Despite the numerical differences in bulk density and height between the ICL and ICLF systems (Table 2), animals took bites with a large volume of forage per bite, so they were able to show similar daily DMI (9.96 and $8.18 \mathrm{~kg} \mathrm{DM.day}{ }^{-1}$ in ICL and ICLF, respectively). The BM values observed in both systems (Table 3) are in accordance with a range of 0.7-1.1. g DM.bite D $^{-1}$ reported for adult cattle grazing temperate pasture of alfalfa and fescue at different heights (Galli et $a l ., 2018)$. It is likely that cattle BM is related to pasture height (Galli et al., 2018) and forage bulk density (Geremia et al., 2018).

Previously, Souza et al. (2019) observed that heifers in ICLF spent more time grazing than those in ICL during the day (from 6:00 to 18:00h). This fact seems to be related to the thermal comfort offered by the trees' shade, since the number of daily grazing sessions and the duration of the grazing sessions did not differ $(P<0.05)$ between systems (ICL vs. ICLF) (Table 3 ). The number of grazing sessions in both systems ( 9 and 8 in ICL and ICLF, respectively) are similar to the range 6-8 observed for adult cattle (Teixeira et al., 2010). In general, the duration of a grazing session is approximately 40minutes (Teixeira et al., 2010), which is close to those observed here (44.72 and 49.04minutes in ICL and ICLF, respectively).

The grazing number and duration are related to forage allowance, which was similar between the two systems (Table 1). In general, these variables are affected by the limitation of forage allowance. In this case, the number of grazing sessions increased in order to compensate for the lower rumen fill and satiety (Melo et al., 2016; Baggio et al., 2008). In this study, animals in both systems had no limitation on the forage allowance (Table 1), which was above the threshold of $12 \mathrm{~kg}$ DM.100kg BW-1 (Hodgson, 1990). Other factors related to these variables are the chemical characteristics of the grass (Maggioni et al., 2009), which were similar between the systems (Table 1) and explained the similarity in number and duration of grazing sessions.

\section{CONCLUSION}

Girolando heifers grazing Xaraés palisade grass have lower bite mass and higher bite rate and daily total bite number in the ICLF system than the ICL system.

\section{ACKNOWLEDGMENTS}

The authors are grateful to Coordination of Superior Level Staff Improvement (CAPES, Brasília, Brazil), Research Support Foundation of Rondônia State (FAPERO, Porto Velho, Brazil; grant\# 0012427578201816.057/2018), and Amazon Found (BNDES, Brasília, Brazil; grant\# 15.2.0897.2 - CID 10200.160036.3) for funding this project. We would like to thank Editage (www.editage.com) for English language editing.

\section{REFERENCES}

ALVARES, C.A.; STAPE, J.L.; SENTELHAS, P.C. et al. Köppen's climate classification map for Brazil. Meteorol. Z., v.22, p.711-728, 2014.

ANKOM Technology method 3. In vitro true digestibility using the DAISYP II incubator. 2017. Available

in: http://www.ankom.com/media/documents/IVDM D_0805_D200.pdf._Accessed in: 5 Nov. 2019.

BAGGIO, C.; CARVALHO, P.C.F.; SILVA, J.L.S. et al. Padrões de deslocamento e captura de forragem por novilhos em pastagem de azevémanual e aveia-pretamanejada sob diferentes alturas em sistema de integração lavoura-pecuária. Rev. Bras. Zootec., v.38, p.215-222, 2009.

BAGGIO, C.; CARVALHO, P.C.F.; SILVA, J.L.S. et al. Padrões de uso do tempo por novilhos em pastagem consorciada de azevém anual e aveia-preta. Rev. Bras. Zootec., v.37, p.19121918, 2008.

BALBINO, L.C.; BARCELLOS, A.O.; STONE, L.F. Marco referencial: integração LavouraPecuária-Floresta (iLPF). Brasília: Embrapa, 2011. 130p.

CAMARGO, D.G.; ROCHA, M.G.; SILVA, J.H.S. et al. Características da ingestão de forragem por cordeiras nos estádios fenológicos da pastagem de azevém. Arq. Bras. Med. Vet. Zootec., v.64, p.403-410, 2012. 
CARVALHO, P.C.F.; RIBEIRO FILHO, H.M.N.; POLI, C.H.E.C. et al. Importância da estrutura da pastagem na ingestão e seleção de dietas pelo animal em pastejo. In: REUNIÃO ANUAL DA SOCIEDADE BRASILEIRA DE 20 ZOOTECNIA, 38., 2001, Piracicaba. Anais... Piracicaba: Sociedade Brasileira de Zootecnia, 2001. p.853-871.

COSTA, V.G.; ROCHA, M.G.; PÖTTER, L. et al. Comportamento de pastejo e ingestão de forragem por novilhas de corte em pastagens de milheto e papuã. Rev. Bras. Zootec., v.40, p.251$259,2011$.

DELAGARDE, R.; PRACHE, S.; D'HOUR, P. et al. Ingestion de l'herbe par les ruminants au pâturage. Fourrages, n.166, p.189-212, 2001.

DETMANN, E.; SOUZA, M.A.; VALADARES FILHO, S.C. et al. Métodos para análise de alimentos. Visconde do Rio Branco-MG: Suprema, 2012. 214p.

FERREIRA, S.F.; FREITAS NETO, M.D.; PEREIRA, M.L.R. et al. Fatores que afetam o consumo alimentar de bovinos. Arq. Pesqui. Anim., v.2, p.9-19, 2013.

FREITAS, E.C.S.; OLIVEIRA NETO, S.N.; FONSECA, D.M. et al. Deposição de serapilheira e de nutrientes no solo em Sistema Agrossilvipastoril com eucalipto e acácia. Rev. Árvore, v.37, p.409-417, 2013.

GALLI, J.R.; CANGIANO, C.A.; PECE, M.A. et al. Monitoring and assessment of ingestive chewing sounds for prediction of herbage intake rate in grazing cattle. Animal, v.12, p.973-982, 2018.

GEREMIA, E.V.; CRESTANI, S.; MASCHERONI, J.D.C. et al. Sward structure and herbage intake of Brachiaria brizantha cv. Piatã in a crop-livestock-forestry integration area. Livest. Sci., v.212, p.83-92, 2018.

GOBBI, K.F.; GARCIA, R.; GARCEZ NETO, A.F. et al. Características morfológicas, estruturais e produtividade do capim-braquiária e do amendoim forrageiro submetidos ao sombreamento. Rev. Bras. Zootec., v.38, p.16451654, 2009.
HIRATA, M.; KUNIEDA, E.; TOBISA, M. Short-term ingestive behaviour of cattle grazing tropical stoloniferous grasses with contrasting growth forms. J. Agric. Sci., v.148, p.615-624, 2010.

HODGSON, J. Grazing management: science into practice. Harlow: Logman Scientific \& Technical, 1990. p.203.

JAMIESON, W.S.; HODGSON, J. The effect of dailyherbage allowance and sward characteristics upon the ingestive behaviour andherbage intake of calves under strip-grazingmanagement. Grass Forage Sci., v.34, p.261-271, 1979.

LIMA, M.A.; PACIULLO, D.S.C.; MORENZ, M.J.F. et al. Productivity and nutritive value of Brachiaria decumbens and performance of dairyheifers in a long-term silvopastoral system. Grass Forage Sci., v.74, p.160-170, 2018.

LOPES, C.M.; PACIULLO, D.S.C.; ARAÚJO, S.A.C. et al.massa de forragem, composiçãomorfológica e valor nutritivo de capim-braquiária submetido a níveis de sombreamento e fertilização. Arq. Bras. Med. Vet. Zootec., v.69, p.225-233, 2017.

MACHADO, A.S.; GODOY, M.M.; LIMA, M.L.M. et al. Utilização de óxido crómico e LIPE® como indicadores externos na estimativa de digestibilidade em ruminantes. PUBVET, v.5, p.1124-1129, 2011.

MAGGIONI, D.; ARAÚJO M.J.; PIZZI R.P. et al. Ingestão de alimentos. Semin. Ciênc. Agrár., v.30, n.4, 2009.

MELO, J.C.; ALEXANDRINO, E.; PAULA NETO, J.J.D. et al. Comportamento ingestivo de bovinos em capim-piatã sob lotação intermitente em resposta a distintas alturas de entrada. Rev. Bras. Saúde Prod. Anim., v.17, p.385-400, 2016.

MEZZALIRA， J.C.; CARVALHO, P.C.D.F.; FONSECA, L. et al. Aspectos metodológicos do comportamento ingestivo de bovinos em pastejo. Rev. Bras. Zootec., v.40, p.1114-1120, 2011.

PROHMANN, P.E.F.; BRANCO, A.F.; PARIS, W. et al. Método de amostragem e caracterização química da forragem consumida por bovinos em pasto consorciado de aveia e azevém. Arq. Bras. Med. Vet. Zootec., v.64, p.953-958, 2012. 
ROCHA, C.H.; SANTOS, G.T.; PADILHA, D.A. et al. Padrões de deslocamento de bovinos em pastos de capim-quicuiu sob lotação intermitente. Arq. Bras. Med. Vet. Zootec., v.68, p.1647-1654, 2016.

SAMPAIO, A.F.; MENDES, F.B.L.; SANTANA JÚNIOR, H.A. et al. Correlação entre comportamento ingestivo e consumo de nutrientes em vacas a pasto. Rev. Cient. Prod. Anim., v.18, p.110-120, 2016.

SANTOS, D.C.; GUIMARÃES JÚNIOR, R.; VILELA, L. et al. Implementation of silvopastoral systems in Brazil with Eucalyptus urograndis and Brachiaria brizantha: productivity of forage and an exploratory test of the animal response. Agric., Ecosyst. Environ., v.266, p.174-180, 2018.

SOUZA, A.N.M.; ROCHA, M.G.; PÖTTER, L. et al. Comportamento ingestivo de novilhas de corte em pastagem de gramíneas anuais de estação quente. Rev. Bras. Zootec., v.40, p.1662-1670, 2011.

SOUZA, E.C.D.; SALMAN, A.K.D.; CRUZ, P.G.D. et al. Thermal comfort and grazing behavior of Girolandoheifers in integrated croplivestock (ICL) and crop-livestock-forest (ICLF) systems. Acta Sci. Anim. Sci., v.41, p.e46483, 2019.
SUÁREZ, E.; REZA, S.; PASTRANA, I. et al. Comportamiento ingestivo diurno de bovinos de ceba en Brachiaria híbrido mulato II. Cienc. Tecnol. Agropecu., v.15, p.15-23, 2014.

TEIXEIRA, F.A.; MARQUES, J.A.; SILVA, F.F. et al. Comportamento ingestivo e padrão de deslocamento de bovinos em pastagens tropicais. Arch. Zootec., v.59, p.57-70, 2010.

THUROW, J.M.; NABINGER, C.; CASTILHOS, Z.M.D.S. et al. Estrutura da vegetação e comportamento ingestivo de novilhos em pastagem natural do Rio Grande do Sul. Rev. Bras. Zootec., v.38, p.818-826, 2009.

VEIT, H.M.; SALMAN, A.K.D.; CRUZ, P.G. et al. Bioacústica comométodo de avaliação do comportamento em pastejo de novilhas Girolando. Arq. Bras. Med. Vet. Zootec., v.70, p.873-880, 2018.

WERNER, J.; UMSTATTERC, C.; KENNEDY, E. et al. Identification of possible cow grazing behaviour indicators for restricted grass availability in a pasture-based spring calving dairy system. Livest. Sci., v.220, p.74-82, 2019.

YAYOTA, M.; KATO, A.; ISHIDA, M. et al. Ingestive behavior and short-term intake rate of cattle grazing on tall grasses. Livest. Sci., v.180, p.113-120, 2015. 